\title{
Trophic importance of kelp-derived suspended particulate matter in a through-flow sub-Antarctic system
}

\author{
S. Kaehler ${ }^{1, *}$, E. A. Pakhomov ${ }^{2,3}$, R. M. Kalin ${ }^{4}$, S. Davis ${ }^{4}$ \\ ${ }^{1}$ Southern Ocean Group, Rhodes University, PO Box 94, Grahamstown 6140, South Africa \\ ${ }^{2}$ Department of Earth and Ocean Sciences, 6339 Stores Road, University of British Columbia, Vancouver, \\ British Columbia V6T 1Z4, Canada \\ ${ }^{3}$ Department of Zoology, Faculty of Science and Technology, University of Fort Hare, Private Bag X1314, \\ Alice 5700, South Africa
}

${ }^{4}$ Environmental Engineering Research Centre, David Keir Building, Stranmillis Road, Queens University, Belfast BT9 5AG, UK

\begin{abstract}
Spatial dynamics of surface chlorophyll concentrations, diatom abundance and carbon and nitrogen stable isotope signatures of surface suspended particulate matter (SPM) were investigated during a bloom event observed in March 2003 in the vicinity of the sub-Antarctic Prince Edward Islands. The surface water composition was studied to estimate the overall importance and spatial extent of kelp derived SPM in the water column of the islands. It was observed that high chlorophyll concentrations (up to $2 \mathrm{mg} \mathrm{m}^{-3}$ ) between and downstream of the islands could not be explained by the development of the diatom bloom. Instead, microscopic and stable isotope analyses suggested that the chlorophyll signal was largely derived from the residual chlorophyll in fresh and decaying particles of small fragments of the kelp Macrocystis laevis, an endemic kelp species abundant along the shoreline of the islands. The findings of this study suggest that the dietary subsidy of kelp-derived carbon and nitrogen to benthic communities and possibly the plankton is not limited to the vicinity of kelp beds, but rather is a widespread phenomenon between the islands. Due to the dominating unidirectional Antarctic Circumpolar Current, large quantities of kelp-derived SPM may be transported and utilised tens of kilometres downstream of the islands.
\end{abstract}

KEY WORDS: Kelp · Suspended particulate matter · SPM • Tropic subsidy · Sub-Antarctic • Stable isotopes

Resale or republication not permitted without written consent of the publisher

\section{INTRODUCTION}

While most pelagic consumers ultimately derive their organic carbon from phytoplankton production, it has long been suggested that the diets of coastal consumers may be subsidized by macroalgal-derived matter (Mann 1973). Only recently, however, with the advent of stable isotope techniques in trophic ecology, has it become possible to directly trace the flow of organic matter from source through to consumers and to establish the relative contribution of macroalgal carbon in various food webs. There is now mounting evidence that the importance of macroalgal- and espe- cially kelp-derived matter in coastal ecosystems has been considerably underestimated (see references in following paragraph).

In addition to the direct consumption of macroalgae by grazers, many benthic and epibenthic consumers assimilate macroalgal carbon through detrital food webs (e.g. Dunton \& Schell 1987, Duggins et al. 1989, Bustamante \& Branch 1996, Norderhaug et al. 2003, Corbisier et al. 2004). Macroalgal-derived carbon in the form of algal fragments and particulate organic matter (POM) have now been shown to not only be a major dietary item of coastal grazers, detritivores and some suspension feeders but also to be ultimately 
assimilated by consumers spanning several trophic levels (Kaehler et al. 2000, Dunton 2001, Fredriksen 2003).

The sub-Antarctic Prince Edward Islands, similar to many other sub-polar and temperate islands and coastlines, are surrounded by dense belts of kelp beds (Attwood et al. 1991). Until recently, however, the potential contribution of kelp to local food webs was largely ignored. This is surprising as kelp production per unit area is an estimated 2 to 3.5 times that of the phytoplankton (Beckley \& Branch 1992). In the past, investigations of the Prince Edward Island's 'life support system', which supports up to 5 million birds and seals, focused on the mechanisms of concentration of allochthonous matter over the island shelf and the localized enhancement of autochthonous phytoplankton production (reviewed by Pakhomov \& Froneman 1999, Pakhomov \& Chown 2003). While there is no doubt that both advection and phytoplankton blooms contribute significantly to local food webs, more recent studies have highlighted the importance of kelpderived carbon to nearshore benthic communities (Kaehler et al. 2000). Subsequently, it was noted that several suspension feeders such as the mussel Gaimardia trapesina and the brachiopod Magellania kerguelenensis also exhibited $\delta^{13} \mathrm{C}$ signatures very close to that of the macroalgae, hinting at the likely existence of a large pool of kelp-derived suspended particulate matter (SPM) in addition to that of the sedimented benthic macroalgal detritus. Any macroalgal-derived SPM originating in nearshore kelp beds is likely to be transported eastward by the continuous flow of the unidirectional Antarctic circumpolar current or retained temporarily over the island shelf by anti-cyclonic eddies in the lee of the islands (Perissinotto \& Duncombe Rae 1990). During either scenario, SPM is likely to become available to suspension feeders tens of kilometres downstream of the islands, at a significant distance from the kelp bed source.

The aims of this study were, firstly, to investigate the occurrence and extent of kelp-derived SPM in the water column near the Prince Edward Islands and, secondly, to compare its potential importance as a trophic subsidy compared to that of the phytoplankton.

\section{MATERIALS AND METHODS}

Surface water. All data were collected during the DEIMEC II cruise (March 2003), in the vicinity of the Prince Edward Islands from on board the MV 'SA Agulhas' (Pakhomov et al. 2003). Water samples from the surface (5 l) were collected at 41 stations, during a sampling polygon between and downstream of the islands (Fig. 1). A further 6 samples were collected

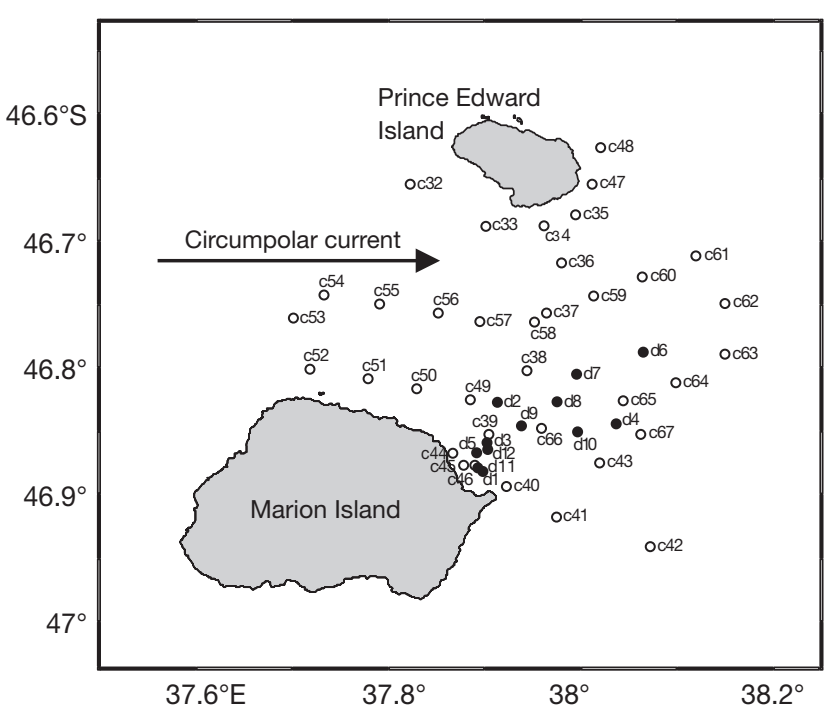

Fig. 1. Location of sampling sites in the vicinity of Prince Edward Islands. Stations preceded by ' $\mathrm{C}$ ' were sampled for surface water. Benthic dredge stations preceded by ' $d$ '. A further 6 surface water stations were located in the kelp beds, inshore of Stns c45 and c46 (not presented here). Stns c52 to c57 were deemed to reflect upstream conditions, as they were similar in chlorophyll and stable isotope signatures, compared to stations further west of the islands that were sampled during a separate study (S. Kaehler unpubl. data)

within the kelp beds, inshore from Stns c45 and c46 (Fig. 1). Aliquots $(250 \mathrm{ml})$ were analysed for size-fractionated chlorophyll, by extraction in $90 \%$ acetone for $24 \mathrm{~h}$ and determination of fluorescence readings on a Turner Designs fluorometer (Holm-Hansen \& Rieman 1978). Fluorescence was determined after size fractionation into pico $(<2.0 \mu \mathrm{m})$, nano $(2.0-20 \mu \mathrm{m})$ and micro $(>20 \mu \mathrm{m})$ size classes by serial filtration (vacuum $<5 \mathrm{~cm} \mathrm{Hg}$ ) using Nitex, Millipore and GF/C filters respectively. A further $250 \mathrm{ml}$ subsample was fixed in $4 \%$ buffered formaldehyde seawater solution for subsequent microscopic examination in the laboratory. Particle composition was determined under an inverted Nikon TMS microscope at 400× magnification, using $10 \mathrm{ml}$ settling chambers. Where possible, diatoms were identified to species level, while other particles/organisms were grouped into higher divisions (e.g. dinoflagellates, silicoflagellates and angular fragments). Degraded kelp fragments were collected from the benthos (see 'Solid samples') and retained for comparison with suspended detritus particles. The remaining $4.5 \mathrm{l}$ of surface water from each station was then filtered through pre-combusted GFF glass-fibre filters for stable isotope determination.

GFF filters were examined under a dissecting microscope and all zooplankton and other visible contaminants removed. Filters were then oven-dried (at $50^{\circ} \mathrm{C}$ 
for $48 \mathrm{~h}$ ) and half of each filter inserted into SerCon tin capsules. Analyses were carried out at the stable isotope facility of the Environmental Engineering Research Centre (Queens University, Belfast). $\delta^{13} \mathrm{C}$ and $\delta^{15} \mathrm{~N}$ were determined on a Micromass Isoprime mass spectrometer, after sample combustion in an on-line Eurovector preparation unit. Leucine and glycine were used as internal standards, calibrated against several International Atomic Energy Agency (IAEA) reference materials. Results are expressed in the standard delta notation, as $X=\left[\left(R_{\text {sample }} / R_{\text {standard }}\right)-1\right] \times 1000$, where $X$ = element in question and $R=$ ratio of the heavy over the light isotope. Repeated analyses of homogeneous material yielded a standard deviation of $0.06 \%$.

Solid samples. In order to examine the importance of kelp-derived material to consumers, both decomposing kelp fragments (Macrocystis laevis; $\mathrm{n}=5$ ) and animal samples (Magellania kerguelenensis; $\mathrm{n}=29$ ) were collected by benthic dredges at various distances downstream of the islands (Fig. 1). Lophophore tissue was dissected from $M$. kerguelenensis for analysis. All samples were then washed in double-distilled water to remove contaminants. Samples were oven-dried (at $50^{\circ} \mathrm{C}$ for $48 \mathrm{~h}$ ), ground into a fine powder and weighed out into tin capsules. Stable isotope analysis was conducted as with GFF filters (see methods above).

\section{RESULTS AND DISCUSSION}

Chlorophyll analyses of surface water indicated an elevated concentration of large photosynthetically derived SPM between and in the lee of the Prince Edward Islands (Fig. 2). More than $80 \%$ of the chlorophyll occurred in the micro-size fraction of the SPM

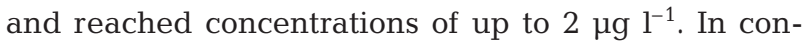
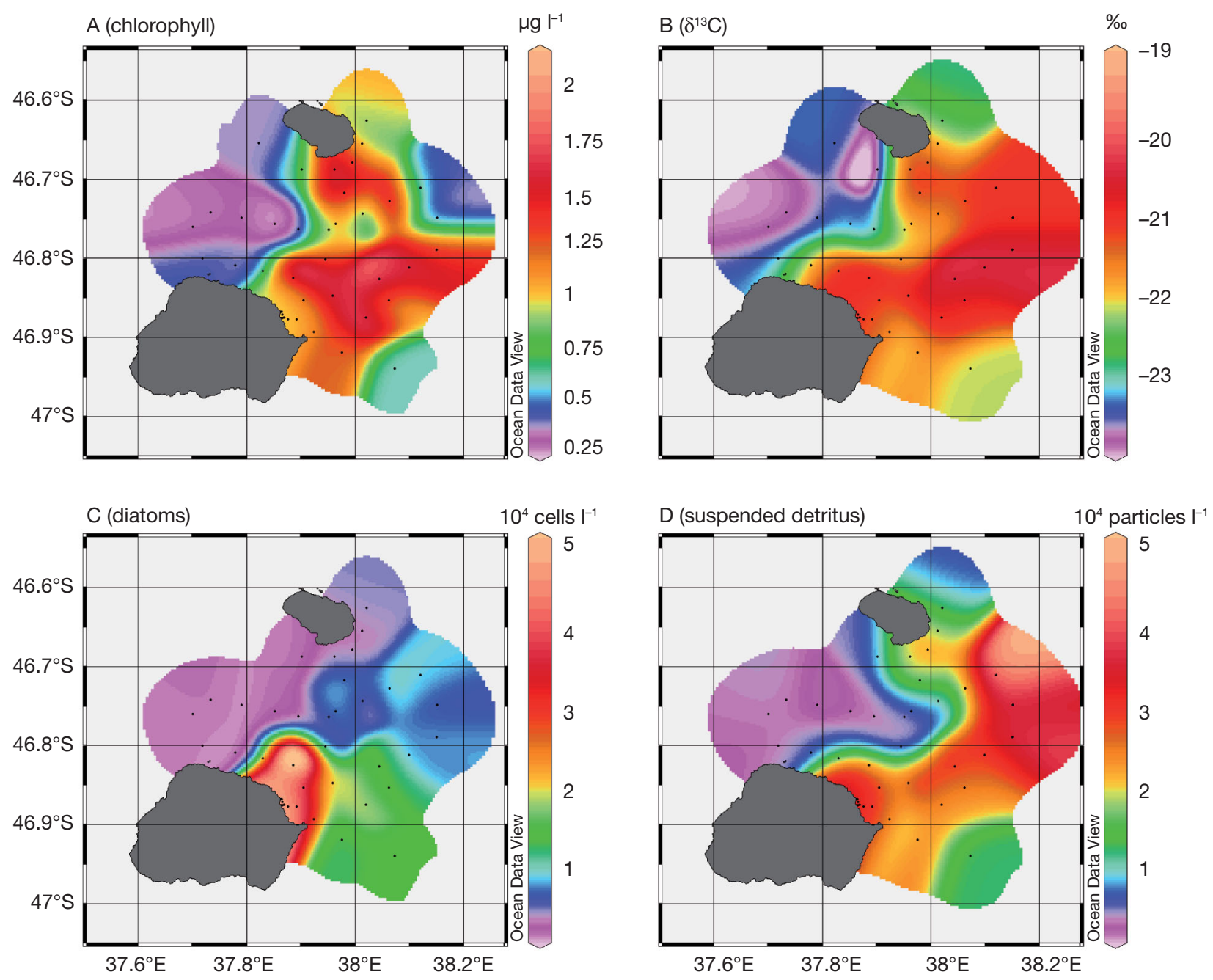

Fig. 2. Surface water composition in the vicinity of the Prince Edward Islands. (A) Chlorophyll concentration of the micro-size fraction; (B) $\delta^{15} \mathrm{C}$ signature of surface suspended particulate matter (SPM); (C) diatom densities; (D) density of suspended angular detritus fragments 
trast, both the nano- and pico- size fractions of the chlorophyll $\left(\max .=0.26 \mu \mathrm{g} \mathrm{l}^{-1}\right)$ and total chlorophyll concentrations upstream of the islands $(\max .=0.11 \mu \mathrm{g}$ $\mathrm{l}^{-1}$ ) were an order of magnitude lower. Several previous studies have shown similar patterns in the microsize fraction of the chlorophyll and linked them to the development of autochthonous diatom blooms (Allanson et al. 1981, 1985, Boden 1988, Ismail 1990, Perissinotto \& Duncombe Rae 1990). In these investigations, it was suggested that, due to increased vertical water stability, nutrient run-off and retention of water over the island shelf, autochthonous production of large bloom-forming diatoms is greatly enhanced between and downstream of the islands. In the present study, microscopic analysis of surface water showed that, independent of location, diatoms were the main constituent of the phytoplankton $(94.4 \% \pm 6.2)$. With the exception of 5 stations north-east of Marion island (mean 43683 cells $1^{-1} \pm 20346$ ), however, overall diatom densities were low $($ mean $=2481 \pm 2361$ ) . Although chlorophyll concentrations reached values close to those associated with bloom conditions in the past $\left(\sim 2 \mu \mathrm{g} \mathrm{l}^{-1}\right)$, diatom densities were low in many areas of high chlorophyll (Fig. 2) and chlorophyll concentrations were not related to and could not be explained by diatom densities (Pearson's correlation; $\mathrm{p}>0.1$ ).

While surface water in the lee of the islands contained only low densities of phytoplankton, large angular detrital fragments made up the bulk of SPM $\left(\right.$ mean $=18578 \pm 12135$ particles $\left.l^{-1}\right)$ and frequently exceeded 30000 particles $1^{-1}$. The distribution of these fragments closely resembled that of the chlorophyll (Fig. 2), and their densities were significantly and positively correlated with micro-size fraction chlorophyll concentrations (Pearson's correlation coefficient $=0.47$; $p=0.002$ ). Due to their large size (3 to 10 times that of the diatoms), their origin could not be planktonic. Indeed, after comparing them with known samples, microscopic investigation confirmed that many of the less decomposed particles were fragments of the kelp Macrocystis laevis. While only a small proportion of total fragments could be identified with certainty (most were degraded), it is likely that due to the generally similar size and shape of the particles much of the downstream SPM was composed of kelp-derived matter. Stable isotope data provided further support for this suggestion.

Stable carbon and nitrogen isotope signatures of decomposing kelp matter dredged from the island shelf $(-19.15 \% \pm \pm 2.77$ and $3.44 \% \pm 0.69$, respectively) were strongly enriched when compared to those of the upstream, phytoplankton-dominated SPM $(-23.51 \%$ 。 0.61 and $-2.83 \% \pm 0.79$, respectively). The 2 main sources of primary production for the islands marine system (allochthonous phytoplankton and autochthonous kelp) could therefore easily be distinguished using stable isotopes. It was shown that there was a significant relationship between the density of detrital fragments in the water and SPM $\delta^{13} \mathrm{C}$ signatures (Pearson's correlation coefficient $=0.64 ; \mathrm{p}<0.001$ ). In the lee of the islands, where detrital fragments were abundant, carbon isotope signatures of the SPM were close to those of decomposing kelp (Fig. 3), while upstream of the islands, where detritus was scarce, $\delta^{13} \mathrm{C}$ values were significantly more depleted (Student's $t$-test; $\mathrm{df}=$ $24, \mathrm{p}<0.001)$. This observation thus provides strong support to the suggestion that a large proportion of detrital SPM originated from kelp production. Between and in the lee of the islands, surface water SPM stable isotope signatures were of intermediate values $\left(\delta^{13} \mathrm{C}=\right.$ $-21.17 \% \pm 0.68 ; \delta^{15} \mathrm{~N}=-0.94 \% \pm 0.46$ ), suggesting that, on average, more than $50 \%$ of the SPM carbon was kelp derived (using a linear mixing model; Bustamante \& Branch 1996).

During a previous investigation of marine food webs at the Prince Edward Islands, it was suggested that inter-island communities were less strongly subsidised by kelp-derived carbon than kelp-associated and nearshore benthic assemblages, as macroalgal detritus was not likely to occur in abundance at great distances from the kelp beds (Kaehler et al. 2000). The current study challenges this suggestion. Not only did kelp particles appear to be the main components of the SPM up to $25 \mathrm{~km}$ downstream of the islands (the spatial extent of the current study), but larger decomposing kelp matter was found to be abundant in all benthic dredges, independent of distance from the islands (authors' pers.

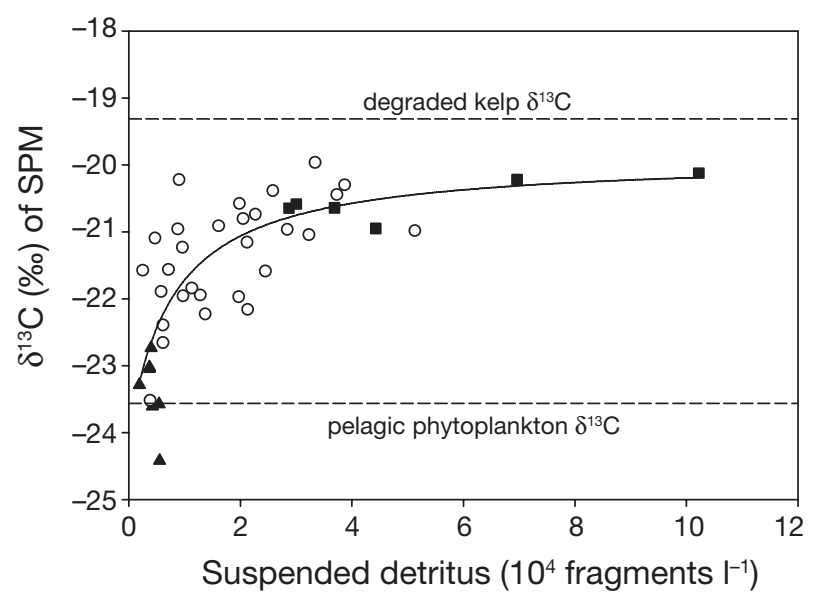

Fig 3. Relationship between density of suspended detritus fragments and $\delta^{13} \mathrm{C}$ signatures of surface water SPM. In samples with high densities of detrital fragments, carbon isotope signatures draw close to those of degraded kelp. Station locations indicated as: within kelp bed $(\mathbf{\square})$, upstream $(\boldsymbol{\Delta})$ and inter-island and downstream $(\mathrm{O})$ 
obs.). It is likely that the contribution of kelp to various consumers was underestimated in the 1999 study, as primarily fresh samples were used for the determination of kelp isotope signatures (Kaehler et al. 2000).

Due to a generally high load of secondary metabolites and low nitrogen content, fresh kelp material is thought to be unpalatable to most consumers. Only after degradation and entry into the detrital cycle has kelp been shown to transform into an important and highly nutritious food source (Duggins \& Eckman 1997, Levinton et al. 2002, Norderhaug et al. 2003). During the current study, kelp for isotopic analysis was obtained from decomposing kelp matter dredged from various distances off the islands and was found to be much more depleted in carbon than fresh material values $\left(\delta^{13} \mathrm{C}=-14.38 \% \pm 3.09 ; \delta^{15} \mathrm{~N}=4.50 \% \pm 0.29\right.$; Kaehler et al. 2000). Whether this depletion in the carbon isotope signature was due to the leaching of certain isotopically enriched substances or due to microbial decomposition is unknown. Whatever the reason, taking into account the more depleted isotopic carbon signature of degraded kelp matter greatly increases the estimated contribution of kelp-derived material to both nearshore and downstream consumers at the Prince Edward Islands.

While in the present study a large proportion of downstream SPM was of kelp origin, it is not fully understood by which mechanism the suspended kelp particles are derived. The shape and size of the angular particles seems to preclude the microbial creation of particles from dissolved organic carbon. Furthermore, due to their relatively small size, it is unlikely that suspended particles were a direct product of kelp frond senescence or fragmentation. More likely is (1) the creation of SPM by the resuspension of previously degraded kelp matter from the benthos and/or (2) the continual cell sloughing from parent plants. Considering that the occurrence of kelp fragment abundance and size coincided with that of the chlorophyll distribution, the suspended kelp detritus may have been relatively fresh and have still contained residual chlorophyll. This suggests that cell sloughing could have been the primary source for particle formation. This suggestion was also supported by the occurrence of freshly produced kelp fragments in extremely high numbers (reaching

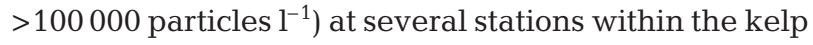
beds. The present study cannot, however, exclude the possibility that kelp fragments in the lee of the islands are populated by photosynthetic epiphytes, thus enhancing chlorophyll concentrations in areas of low phytoplankton/high kelp-particle densities. Further investigations are clearly required to explain both the mechanisms by which detrital SPM is derived and to determine the temporal extent to which kelp derived matter is found in the water column.
Whatever the source of kelp-derived SPM, suspension feeders downstream of the islands exhibited isotopic signatures that could only be explained by the incorporation of a mixture of phytoplankton and kelp detritus. Both carbon and nitrogen signatures $(-20.72 \% \pm 0.68$ and $3.99 \% \pm \pm 1.11$, respectively) of the suspension-feeding brachiopod Magellania kerguelenensis were very close to that of the downstream 'mixed' SPM (taking into account an average 0.8 and $3.6 \%$ fractionation for carbon and nitrogen per trophic level; Fry \& Scherr 1984, Owen 1987, France \& Peters 1997) and were too enriched to be explained by the consumption of phytoplankton alone (Fig. 4). All other known sources of primary production such as autochthonous diatom blooms $\left(\delta^{13} \mathrm{C}\right.$ and $\delta^{15} \mathrm{~N} \approx-23.34$ and $4.09 \%$, respectively) and deep-water rhodophytes $\left(\delta^{13} \mathrm{C}\right.$ and $\delta^{15} \mathrm{~N} \approx-33.42$ and $3.44 \%$, respectively) have isotopic signatures that are too depleted (Kaehler et al. 2000, authors' unpubl. data) to account for the relatively enriched diet of $M$. kerguelenensis. Using a linear mixing model for a 2-source system (Bustamante \& Branch 1996), it was estimated that on average $41 \%$ of the brachiopods time-integrated, assimilated carbon originated from kelp-derived matter. The dietary subsidy of kelp-derived matter to the brachiopods decreased significantly with distance from the islands (Pearson's correlation coefficient $=-0.35 ; \mathrm{p}=0.001$ ), but even at a distance of $>14 \mathrm{~km}$, almost $25 \%$ of the consumers carbon intake still originated from kelpproduction (Fig. 4). This strongly suggests that the dietary subsidy of kelp-derived carbon is far more widespread than previously anticipated and not limited to the immediate vicinity of the kelp beds. It may

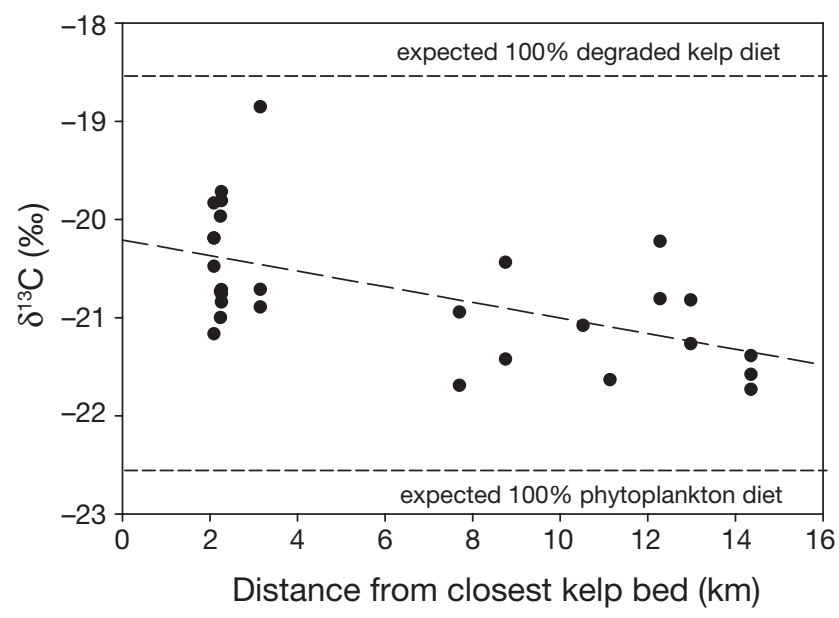

Fig. 4. Magellania kerguelenensis. $\delta^{13} \mathrm{C}$ signatures of suspension-feeding benthic brachiopods dredged at different distances from kelp beds. Estimated $100 \%$ diet lines were calculated using an average trophic enrichment of $0.8 \%$ for carbon (Fry \& Scherr 1984, France \& Peters 1997) 
further be postulated that due to the suspended nature of the macroalgal matter and the strong unidirectional circumpolar current dispersal of detritus is greatly enhanced and may, on future investigation, be found to contribute to the diets of downstream plankton as well as benthic communities.

Acknowledgements. We thank the South African Department of Environmental Affairs and Tourism for providing funds for this study through the South African National Antarctic Programme. Thanks also to students, officers and crew on the DEIMEC II cruise for logistic support and cooperation.

\section{LITERATURE CITED}

Allanson BR, Hart RC, Lutjeharms JRE (1981) Observations on the nutrients, chlorophyll and primary production of the Southern Ocean south of Africa. S Afr J Antarct Res 10:13-14

Allanson BR, Boden BP, Parker LD, Duncombe Rae CM (1985) A contribution to the oceanography of the Prince Edward Islands. In: Siegfried WR, Condy PR, Laws RM (eds) Antarctic nutrient cycles and food webs. Springer Verlag, Berlin, p 38-45

Attwood CG, Lucas MI, Probyn TA, McQuaid CD, Fielding PJ (1991) Production and standing stocks of the kelp Macrocystis laevis Hay at the Prince Edward Islands, Subantarctic. Polar Biol 11:129-133

Beckley LE, Branch GM (1992) A quantitative scuba-diving survey of the sublittoral macrobenthos at subantarctic Marion Island. Polar Biol 11:553-563

Boden BP (1988) Observations of the island mass effect in the Prince Edward Archipelago. Polar Biol 9:61-68

Bustamante RH, Branch GM (1996) The dependence of intertidal consumers on kelp-derived organic matter on the west coast of South Africa. J Exp Mar Biol Ecol 196:1-28

Corbisier TN, Petti MAV, Skowronski RSP, Brito TAS (2004) Trophic relationships in the nearshore zone of Martel Inlet (King George Island, Antarctica): $\delta^{13} \mathrm{C}$ stable-isotope analysis. Polar Biol 27:75-82

Duggins DO, Eckman JE (1997) Is kelp detritus a good food for suspension feeders? Effect of kelp species, age and secondary metabolites. Mar Biol 128:489-495

Duggins DO, Simenstad CA, Estes JA (1989) Magnification of secondary production by kelp detritus in coastal marine ecosystems. Science 245:170-173

Editorial responsibility: Otto Kinne (Editor-in-Chief), Oldendorf/Luhe, Germany
Dunton KH (2001) $\delta^{15} \mathrm{~N}$ and $\delta^{13} \mathrm{C}$ measurements of antarctic peninsular fauna: trophic relationships and assimilation of benthic seaweeds. Am Zool 41:99-112

Dunton KH, Schell DM (1987) Dependence of consumers on macroalgal (Laminaria solidungula) carbon in an arctic kelp community: $\delta^{13} \mathrm{C}$ evidence. Mar Biol 93:615-625

France RL, Peters RH (1997) Ecosystem differences in the trophic enrichment of ${ }^{13} \mathrm{C}$ in aquatic food webs. Can J Fish Aquat Sci 54:1255-1258

Fredriksen S (2003) Food web studies in a Norwegian kelp forest based on stable isotope $\left(\delta^{13} \mathrm{C}\right.$ and $\left.\delta^{15} \mathrm{~N}\right)$ analysis. Mar Ecol Prog Ser 260:71-81

Fry B, Sherr EB (1984) $\delta^{13} \mathrm{C}$ measurements as indicators of carbon flow in marine and freshwater ecosystems. Contr Mar Sci 27:13-47

Holm-Hansen O, Rieman B (1978) Chlorophyll-a determination: inprovements in methodology. Oikos 30:438-447

Ismail HE (1990) Surface nutrients in the vicinity of the Prince Edward Islands during April/May 1989. S Afr J Antarct Res 20:33-36

Kaehler S, Pakhomov EA, McQuaid CD (2000) Trophic structure of the marine food web at the Prince Edward Islands (Southern Ocean) determined by $\delta^{13} \mathrm{C}$ and $\delta^{15} \mathrm{~N}$ analysis. Mar Ecol Prog Ser 208:13-20

Levinton JS, Ward JE, Shumway SE (2002) Feeding responses of the bivalves Crassostrea gigas and Mytilus trossulus to chemical composition of fresh and aged kelp detritus. Mar Biol 141:367-376

Mann KH (1973) Seaweeds: their productivity and strategy for growth. Science 182:975-981

Norderhaug KM, Fredriksen S, Nygaard K (2003) Trophic importance of Laminaria hyperborea to kelp forest consumers and the importance of bacterial degradation to food quality. Mar Ecol Prog Ser 255:135-144

Owens NJP (1987) Natural variation in ${ }^{15} \mathrm{~N}$ in the marine environment. Adv Mar Biol 24:389-451

Pakhomov EA, Chown SL (2003) The Prince Edward Islands: Southern Ocean oasis. Ocean Yearb 17:348-379

Pakhomov EA, Froneman PW (1999) The Prince Edward Island pelagic ecosystem, south Indian Ocean: a review of achievements, 1976-1990. J Mar Syst 18:355-367

Pakhomov EA, Ansorge IJ, Kaehler S, Vumazonke LU and 12 others (2003) Studying the impact of ocean eddies on the ecosystem of the Prince Edward Islands: DEIMEC II. S Afr J Sci 99:187-190

Perissinotto R, Duncombe Rae CM (1990) Occurrence of anticyclonic eddies on the Prince Edward Plateau (Southern Ocean): effects on phytoplankton biomass and production. Deep-Sea Res 37:777-793

Submitted: February 16, 2005; Accepted: December 12, 2005 Proofs received from author(s): June 7, 2006 